Jiang, J., Chen, M., \& Zhang, J. (2020). Analyses of Elderly Visitors' Behaviors to Community Parks in Shanghai and the Impact Factors. Landscape Architecture Frontiers, 8(5), 94-109.

https://doi.org/10.15302/J-LAF-1-020038

\section{上海市社区公园老年游客活动差异及 影响因素探究 \\ ANALYSES OF ELDERLY \\ VISITORS' BEHAVIORS TO \\ COMMUNITY PARKS \\ IN SHANGHAI AND \\ THE IMPACT FACTORS}

姜佳怡

日本干叶大学园艺学研究科绿地造园学博士候选人, Needle景观城市实验室学术研究员

陈明*

华中科技大学建筑与城市规划学院讲师

章俊华

日本干叶大学园艺学研究科绿地造园学博士风景园林学教授

\section{JIANG Jiayi}

PhD Candidate of Graduate of Horticulture, Landscape Architecture, Chiba University; Researcher at the Needle Studio

\section{CHEN Ming}

Lecturer at the School of Architecture and Urban Planning, Huazhong University of Science and Technology

\section{ZHANG Junhua}

Professor of Graduate of Horticulture, Landscape Architecture, Chiba University

\section{太通讯作者}

地址: 湖北省武汉市洪山区珞喻路1037号

地编: 430074

那箱: hustchenming@163.con
摘要

随着全球越来越多的地区步入老龄化社会, 关于人口老龄化与城市发展关系的研究日渐广 泛。上海市作为中国人口密度最高且最早步入老 龄化社会的城市, 正面临严峻的人口老龄化问 题。本文以上海市社区公园为例，基于中心城区 和非中心城区的城市结构差异，利用手机信令数 据获取老年人的时空行为, 建立多元线性回归模 型，分析了老年人访问社区公园的差异及其影响 因素, 包括人口密度、老年人自居住地到社区公 园的出行距离、城市设施密度等。结果表明, 居 住地的人口密度及其老龄人口密度、出行距离是 影响老年人访问社区公园的三个重要因素, 且中 心城区和非中心城区社区公园老年游客使用社区 公园的影响机制存在差异。有必要针对不同区域 的社区公园提出相应的规划设计准则，完善老年 人友好型社区公园布局, 以落实近年来大力推进 的社区养老工作, 推动健康公平。

\section{关键词}

老龄化; 社区公园; 手机信令; 公园使用; 多源大 数据; 上海市; 生活圈

\section{ABSTRACT}

As more and more regions step into the aging society all over the world, research on the relationship between population aging and urban development becomes more extensive. Shanghai, one of the densely-populated cities, is faced with severe population aging problems. Focusing on the disparities between the city's central and outer districts, this study evaluates elderly visitors' behaviors to community parks in Shanghai and related impact factors via mobile phone signaling data (conveying the spatiotemporal behavioral patterns of the elderly) and a multiple linear regression equation. The researched factors included popularity density, the traveling distance from the elderly's living places to community parks, urban facility density, etc. The results suggested that both the total and elder population density, and the traveling distance had significant impacts on the elderly's visiting behaviors. Moreover, the impact mechanism differ between the central and outer districts. Therefore, specific planning and design guidance for different districts should be proposed to optimize the community park layout so as to promote community support for the elderly care and health justice.

\section{KEYWORDS}

Aging; Community Park; Mobile Phone Signaling; Park Usage; Multi-Source Big Data; Shanghai; Life Circle

\section{基金项目}

中央高校基本科研业务费专项资金 (编号: 2020kfyXJJS104)

RESEARCH FUND

Fundamental Research Funds for the Central Universities (No. 2020kfyXJJS104)

编辑 崔婧沄王颖 翻译 王颖 姜佳怡

EDITED BY CUI Jingyun WANG Ying TRANSLATED BY WANG Ying JIANG Jiayi 


\section{1 研究背景}

2000年, 第五次全国人口普查结果显示, 中国已步人老龄化社 会。由国家统计局发布的《中华人民共和国2019年国民经济和社会发 展统计公报》显示, 截至2019年末, 中国60岁以上老龄人口超过 2.5 亿, 占总人口的 $18.1 \%$ \% $^{[1]}$ 。放眼全球, 随着越来越多的地区步人老龄化 社会, 人口老龄化与城市发展的关系成为了广泛讨论的议题; 而城市 公园作为公共服务设施的重要组成部分, 对保持居民身心健康, 提升 城市经济、社会、环境效益等具有重要意义 ${ }^{[2-[4]}$, 不少研究也聚焦于城 市公园绿地对老年人身心健康的影响。例如, 谢波等人针对武汉 30 个 社区60岁以上老年人访问公园的情况展开调研, 而后对武汉市主要社 区公园和综合性公园老年人游客满意度进行评分; 并使用单独的逻辑 回归模型, 建立了老年人慢性疾病发生率与老年人的公园可达性之间 的关系, 发现更多地访问城市公园能够有效降低老年人慢性疾病的患 病率 $^{[3]}$ 。

21 世纪以来, 世界卫生组织和地区相关机构陆续出台老年人友 好型城市 ${ }^{[5]}$ 及公园 ${ }^{[6]}$ 设计指南。近年来的研究开始关注老年人访问 城市公园绿地的行为特征及影响因素、环境公平等方面 ${ }^{[7]-[9]}$ 。例如,

娜嘉・卡比施和达格玛 - 哈泽调查了德国柏林市外来移民和老年人 ( 65 岁及以上）的公园绿地可达性及使用现状, 研究通过分析不同社会群 体的人均公园绿地面积阈值及使用偏好, 揭示了柏林老年人人均绿地 面积显著偏低, 城市绿地难以满足老年人需求等问题]。郭思慧等人基 于移动手机信令数据及两步移动搜索法, 探讨了北京市老年人进人城 市公园绿地的公平性, 发现公园可达性受其居住地与商业区及公园 的距离、居住地房价等影响较大 ${ }^{[8]}$ 。考虑到老年人更易受到个体机能 及周边环境等因素的影响, 其出行方式及出行距离所受限制更高 ${ }^{[3][]}$, 社区公园作为主要服务于居民日常休闲活动的城市绿地, 对丰富老年 人日常活动、提高老年人生活品质有重要意义。但是, 正如文晨等人 在对老年人城市公园使用情况的研究中所指出的，老年人访问特定类 型城市公园的活动特征及影响因素仍存在较大的研究空白 ${ }^{[9]}$ 。

\section{Research Background}

According to the Fifth National Population Census in 2000, China has entered the aging society. Stated by the Statistical Communique of the People's Republic of China on the 2019 National Economic and Social Development, by the end of 2019 , the population aged above 60 reached over 250 million, accounting for $18.1 \%$ of the tota $\mathrm{l}^{[1]}$. Worldwide, as more and more regions are entering aging societies, elderly-friendly urban development become an increasingly discussed topic. Urban parks, as important public service facilities, have been proven their positive impact on improving people's physical and mental health and boosting the economic, social, and environmental benefits for cities $^{[2] \sim[4]}$. A number of existing studies concentrate on the group of elderly users. For instance, based on the investigation of the park usage by the citizens aged above 60 in 30 communities, Xie Bo et al. scored their satisfaction degrees to major community parks and general parks in Wuhan, China. The research found that a higher accessibility of urban parks is associated with a reduced risk of chronic diseases, by exploring the correlation between the prevalence of chronic diseases and the accessibility of parks with a logistic regression $\operatorname{model}^{[3]}$.

Since the 21st century, the World Health Organization (WHO) and related regional health care agencies have developed guidelines on the design of elderly-friendly cities ${ }^{[5]}$ and parks ${ }^{[6]}$. Recent studies examine the behavioral patterns of the elderly in urban parks and associated impact factors, and environmental justice ${ }^{[7] \sim[9]}$. Nadja Kabisch and Dagmar Haase studied the accessibility and usage of urban parks among the migrants and the senior citizens (aged 65 and above) in Berlin. The per capita park area and the use preferences of different social groups suggested a significantly low level of per capita green area and the insufficiency in satisfying senior users' needs ${ }^{[7]}$. Guo Sihui et al., with the mobile phone signaling data and the two-step floating catchment area method, discussed the justice of the elderly's access to urban parks in Beijing, and found that the distance to commercial areas and green spaces, as well as the housing price of the elderly's living places, would significantly impact the park accessibility ${ }^{[8]}$. Considering the elderly's phycical activity and functional limitations and that they are more affected by the environment, their traveling modes and distance are often limited $^{[3][7]}$. For this reason, community parks, as daily recreational spaces for residents, can significantly enrich the outdoor activities of the elderly and enhance their life quality. Nonetheless, as stated by Wen Chen et al. in the study on the park usage by the elderly, research gap still exists on the elderly's visiting patterns to certain types of urban parks and related impact factors ${ }^{[9]}$. 
20世纪以来, 结合社交媒体、手机定位信息等多源大数据 ${ }^{[10]}$ 的城 市规划观念开始进人研究者的视野, 手机等可佩戴设备记录使用者的 位置 (经纬度) 、活动行为及时间等信息, 汇集为智慧城市建设的大 数据集, 是获取人群时空行为特征、分析城市公共空间使用情况的重 要数据来源。通过脸书和推特等社交媒体软件可有效获取公园游客发 布的博文, 进而研究游客情绪、活动类型及活动需求。但在中国, 微 博、绿洲等主要社交媒体软件的用户年龄集中在16 41岁（占全部用户 的95\% ） ${ }^{[11]}$, 并未覆盖大多数中老年游客。与此相对的是, 截至2018年 底, 中国手机用户达到15亿吕]。此外, 2017年, 中国移动、中国联通及 中国电信 47 岁以上用户占比分别为 $20.1 \% 、 17.9 \%$ 和 $20.7 \%$ [13]。可见, 相 比社交媒体等数据来源, 手机信令数据覆盖范围更广。手机信令数据 已用于研究不同年龄段用户的公园访问行为。例如，肖扬等人基于手 机信令数据评估了居住隔离与上海市绿地的公平性关系 ${ }^{[14]}$; 刘耀林等人 基于城市土地利用数据及手机信令数据, 首次将重力模型与调整后的 回归模型应用到通勤行为预测中，评估了武汉市通勤流与不同城市土 地利用类型的关系 ${ }^{[15]}$ 。结合手机信令数据与城市空间结构数据、经济和 人口数据等多源大数据, 可实现对城市空间结构及居民时空行为的研 究 ${ }^{[10[15]}$ 。此外, 随着中国城镇化进程的推进, 中心城区与非中心城区间 的城市分化影响了不同区域内的居民前往绿地的出行行为 ${ }^{[3][14|16| 117]}$ 。因 此, 有必要关注中心城区与非中心城区老年人的公园访问差异, 并结 合出行距离、出行方式及周边环境等因素分析相关原因。

上海市人口密度高, 不仅是中国最早进人老龄化社会的城市, 也 是老龄化程度较高的城市之一 ${ }^{[18]}$ 。为保障和提升老年人生活质量, 对 老年人访问社区公园的现状研究有迫切需求。鉴于此, 本研究聚焦于 上海市, 旨在通过手机信令数据及城市设施数据获取老年人 ${ }^{\circledR}$ 的时空行 为, 并基于人口年龄及城市结构差异，分析老年人访问社区公园的活 动差异及影响机制, 以此来探究老龄化社会背景下老年人使用社区公 园的现状，进而完善老年人友好型社区公园布局，落实上海市近年来 大力推进的社区养老工作, 推动健康公平。研究的重点包括：1）城市
Since the 20th century, researchers began to combine urban planning with multi-source data sourced from social media and mobile phone positioning applications ${ }^{[10]}$. Wearable devices such as mobile phones log users' data of locations (longitude and altitude), traveling patterns, and time, forming big data sets that can be used to analyze spatiotemporal behavior characteristics of the population and the usage of public space, which benefits the construction of smart cities. Usually, researchers could learn users' perception or feelings, activity types, and needs or desires from the posts on social media, such as Facebook and Twitter. But in China, most users of major social media software (such as Weibo and Oasis) are 16 to 41 years old (accounting for $95 \%$ of the total) ${ }^{[11]}$, yet to cover the majority of senior users. Meanwhile, by late 2018, mobile phone users in China totaled 1.5 billion $^{[12]}$; in 2017, users of the three major telecom operators (China Mobile, China Unicom, and China Telecom) aged above 47 accounted for $20.1 \%, 17.9 \%$, and $20.7 \%$, respectively ${ }^{[13]}$. This means a wider coverage on the elderly users by the mobile phone signaling data. Such data have already been applied in the research on users' park visiting behaviors in different age groups. For example, Xiao Yang et al. evaluated the inequality of citizens' access to green spaces in Shanghai caused by residential segregation ${ }^{[14]}$. Liu Yaolin et al., based on the urban land use data and the mobile phone signaling data, innovatively combined the gravity model with the adjusted regression model to predict citizens' commuting behaviors, and to evaluate the relationship between the commuting flow and different land use types in Wuhan ${ }^{[15]}$. The mobile phone signaling data, and data in urban space structure, economy, and demography can be used to study urban space structures and residents' spatiotemporal behaviors ${ }^{[10][15]}$. Along with the advance of China's urbanization, disparities between the central and outer districts affect residents' visiting behaviors to green spaces ${ }^{[3][14][16][17]}$. It is therefore necessary to study the park visiting differences between the elderly in both areas by analyzing impact factors such as traveling distance, traveling modes, and surrounding environments.

Homing a dense population, Shanghai is one of the first aging cities in China with a high aging rate ${ }^{[18]}$. Studies on the elderly users' visiting behaviors to community parks are in urgent need, as references to the improvement of senior citizens' life quality. To this end, we utilized mobile phone signaling data and urban facility data to analyze the spatiotemporal behavioral patterns of the elderly / aging population ${ }^{(1)}$ in community parks in Shanghai. Their behavioral differences and related impact factors were analyzed based on the city's population ages and urban structures. The findings would serve as the basis to improve the layout design of elderly-friendly community parks, thus enhancing the community support for elderly care and promoting health justice.
1) 本研究依据世界卫生组 织及上海市统计局的定 义, 将年龄为 60 岁及以 上的人群定义为“老年 人/老龄人口”。

(1) This study adopted the definitions by WHO and Shanghai Municipal Statistics Bureau that "the elderly / aging population" are the people aged 60 and above. 
分化导致的上海市中心城区与非中心城区 (以中心城区行政边界为划 分依据）结构差异是否对老年人的社区公园使用情况造成影响；2）如 是, 基于多元线性回归模型, 探究中心城区与非中心城区老年人社区 公园使用情况的潜在影响因素，并分析二者差异；3）提出相应的规划 设计建议。

\section{2 社区公园选取与影响因素划定}

\section{1 研究区域概况}

上海市下辖 16 个区, 总面积 $6340.5 \mathrm{~km}^{2}$ 。2019年, 常住人口 约 2423.14 万人, 其中 60 岁及以上人口约 806.87 万人 (占 $33.30 \%)^{[19]}$ 。 上海市是崛起于工业时代的中国经济中心, 在带动长三角都市圈发展 方面发挥着领导作用。自1979年步人老年型城市行列以来, 城市发展 建设与人口老龄化的双重压力对上海市的城市规划提出了挑战。近年 来，为平衡城市空间结构差异对居民生活和城市可持续发展的影响， 上海市正在向多功能中心城市转型 ${ }^{[20]}$ 。上海市规划和自然资源管理局 ( 原上海市规划和国土资源管理局 ) 于2016年提出建成 “15分钟社区 生活圈” (2) (面积范围为 $3 \sim 5 \mathrm{~km}^{2}$ ) 的规划目标, 强调了针对不同人群需 求进行差异化公共设施配置的必要性 ${ }^{[21] \sim 23]}$ 。由此, 社区成为了上海打 造社区生活圈的基本单元。2017年，上海新一轮城市规划建议将 $500 \mathrm{~m}$ 作为公共设施和社区绿地步行的距离单位, 并强调了城市绿地对提高 城市活力的重要作用 ${ }^{[24]}$ 。此外, 上海的高速城镇化进程、收人差距等因 素导致了中心城区和非中心城区在城市结构、功能布局及社会福祉等 方面的差距 ${ }^{[14][16]}$ 。研究中心城区和非中心城区城市结构差异下的老年人 使用社区公园的现状及影响因素，对完善社区生活圈中的绿地建设具 有重要意义

\section{2 对象选取}

根据上海市市容和绿化管理局的统计数据, 截至2019年, 上海市 共有公园352个。根据《城市绿地分类标准CJJ / T85-2017》的定义, 社 区公园是位于一定居住用地范围内, 主要服务对象为周边居民的公园 绿地 ${ }^{[25]}$ 。综合城市公园相关研究 ${ }^{[26]-[28]}$ 、上海市相关绿地研究 ${ }^{[14][29]}$ 及绿化
The study first discussed whether urban differentiation (i.e. central and outer districts in Shanghai, bordered by the administrative boundaries) affects senior users' usage of community parks. If so, the possible impact factors on the differences would be analyzed with the multiple linear regression model. Then suggestions on the planning and design of urban community parks would be proposed accordingly.

\section{The Selection of Community Parks and Impact Factors}

\subsection{Research Area}

Shanghai administers 16 districts, occupying a land of $6,340.5 \mathrm{~km}^{2}$. The permanent population in 2019 was 24.2314 million, 8.0687 million of which was aged 60 and above $(33.30 \%)^{[19]}$. Shanghai is well known for being China's economic hub and has played a leading role in promoting the development of the Yangtze Delta metropolitan area since the Industrial Era. Since 1979 when ranking as an aging city, both urban development and population aging problems have been challenging Shanghai's urban planning. Recently, transforming into a multi-functional pivotal city, Shanghai attempts to mitigate the impact of the differentiations of urban spatial structure on residents' living conditions and the city's sustainable development ${ }^{[20]}$. In 2016, Shanghai Municipal Bureau of Planning and Natural Resources (the former Shanghai Urban Planning and Land Resources Administration Bureau) launched the initiative of "15-Minute Community-Life Circle"(2) (with a coverage of $3 \sim 5 \mathrm{~km}^{2}$ ), which emphasizes a differentiated planning of public facilities to meet diverse needs of different user groups ${ }^{[21] \sim[23]}$, and formulates community as the basic unit of community-life circle. In 2017, the new urban planning determined 500 meters as an acceptable walking distance to the surrounding public facilities and community parks, and highlighted the significant role of urban green spaces in boosting the city's vitality ${ }^{[24]}$. In addition, the rapid urbanization and the income gap result in disparities between the central and outer districts regarding the urban structure, land use, and social welfare ${ }^{[14][16]}$. A focus on the differences of elderly visitors' behaviors to community parks and related impact factors between these two areas may contribute to the improvement of the city's green space construction in community-life cycles.

\subsection{Community Park Selection}

According to the statistics by Shanghai Landscaping and City Appearance Administrative Bureau (SLCAAB), there were 352 parks in the city by 2019; and community parks, as defined by the Urban Green Space Classification Standard CJJ / T85-2017, are green spaces that serve the residents living nearby within a certain distance $^{[25]}$. Referring from related studies on urban parks ${ }^{[26] \sim 28]}$ 
和市容管理局发布的社区公园定义 ${ }^{[30]}$, 参考国内外各城市社区公园面积 标准 ${ }^{[3] 1[32]}$, 并结合数据获取精度的影响, 本研究选取面积为 $2 \sim 6 \mathrm{hm}^{2}$ 的公 园作为研究对象。考虑到上海市社区生活圈 $3 \sim 5 \mathrm{~km}^{2}$ 的规划目标, 进一 步篮选内切圆直径为 $2 \mathrm{~km}$ 的正六边形范围 ${ }^{[33]}\left(\mathrm{S}=3.46 \mathrm{~km}^{2}\right)$ 内居住用地 大于 $50 \%$ 的公园。最终, 将本研究的社区公园样本限定为：1）向公众 免费开放；2）具备一定规模（面积达标）；3）分别位于中心城区老 龄化程度最高的虹口区、黄浦区、普陀区和非中心城区老龄化程度最 高的崇明区、宝山区、和嘉定区 ${ }^{[19]} ; 4$ ) 公园所在正六边形范围内居住 用地占比达 $50 \%$ 以； 5 ) 非综合性公园 / 非专类公园。依据上述标准, 篮选出中心城区和非中心城区各6个代表性社区公园（表1, 图1）。

\section{3 老年人访问社区公园的活动特征及影响因素}

研究表明, 老年人访问社区公园的特征主要受身体机能与年龄及 周边城市设施服务质量、城市功能混合度影响 ${ }^{[3]}$, 而这些因素均与老年 人访问社区公园的出行距离和方式选择有关。此外, 人口密度是影响

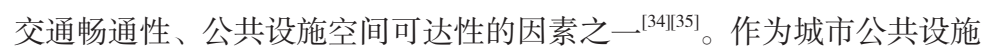
的重要组成部分, 公园绿地的使用情况及服务质量也必然受到人口密 度的影响 ${ }^{[36]}$

因此, 本研究以社区公园周边及老年人居住地周边城市设施的 分布情况（城市功能混合度）、老年人自居住地到社区公园的出行距 离、人口密度等作为老年人访问社区公园的主要影响因素。

\section{3 研究方法}

\section{1 研究数据}

本研究采用的数据包括:

1 ) 主要公园边界数据, 来自高德地图兴趣面 ( AOI), 获取时间 为2019年10月。

2 ）城市边界、城市道路及公共交通站点分布数据, 来源于上海市 绿化和市容管理局。

3 ) 城市设施数据, 来自高德地图公共兴趣点（POI）, 获取时间 and green spaces in Shanghai ${ }^{[14][29]}$, the definition of community park by SLCAAB ${ }^{[30]}$, the size standards on community parks at home and abroad ${ }^{[31][32]}$, and the accuracy of available data, this research selected the community parks whose area ranges from 2 to $6 \mathrm{hm}^{2}$. Conforming to the city's planning goal of establishing community-life circles of 3 to $5 \mathrm{~km}^{2}$, the selection scope was further narrowed down to the parks where the residential land accounts for over $50 \%$ within each regular hexagon grid $^{[3[33]}$ (the diameter of its inscribed circle is $2 \mathrm{~km}$ and $\mathrm{S}=3.46 \mathrm{~km}^{2}$ ). In general, the selected community parks are the ones that 1 ) are open to the public for free; 2) cover an area of 2 to $6 \mathrm{hm}^{2} ; 3$ ) are located in the central Hongkou District, Huangpu District, and Putuo District, and the outer Chongming District, Baoshan District, and Jiading District, all of which are with high aging population rate ${ }^{[19]}$; 4 the residential land within the regular hexagon where the park is located accounts for over $50 \%$; and 5 ) are not general or dedicated parks. Finally, 6 community parks in central districts and another 6 in outer districts were chosen (Table 1, Fig. 1).

\subsection{Elderly Users' Visiting Behaviors to Community Parks and \\ Related Impact Factors}

Existing studies suggest that factors which influence the elderly's choice on traveling distance and mode to visit community parks include their physical function, age, the service quality and the mixture degree of the surrounding urban facilities ${ }^{[3]}$. In addition, the population density, which partly decides the traffic flow and accessibility to public facilities (including parks) ${ }^{[34][35]}$, also impacts the park usage and service quality $^{[36]}$.

To this end, we examined elderly users' visiting behaviors to community parks by analyzing the distribution of urban facilities in the surrounding of the studied community parks and elderly visitors' living places (i.e. the mixture degree of urban facilities), the distance to the community park, and the population density of the communities where the elderly users live.

\section{Research Method}

\subsection{Data Processing}

The data used for this research were from the following sources:

1) AMAP with Area of Interest (AOI), for the data of urban park boundaries, acquired in October 2019.

2) SLCAAB, for the data of city boundaries, and the location distribution of main roads and public transportation stations.

3) AMAP with Point of Interest (POI), for the data of urban facilities, acquired in July 2019; each item of data includes the 较弱, 适宜进行出行行 为分析 ( 来源：参考文 献[33]）。 hexagon grids is due to its weak margina effects, which is suitable for the analysis of visitors' traveling behaviors (Source: Ref. [33]). 
表1: 上海市社区公园及老龄人口基本信息

Table 1: Basic information of community parks and the elderly population in Shanghai

\begin{tabular}{|c|c|c|c|c|c|}
\hline \multicolumn{2}{|c|}{$\begin{array}{l}\text { 所在区域 } \\
\text { Region }\end{array}$} & $\begin{array}{c}\text { 60岁及以上人口数量占行政区总人口比例 ( \% ) } \\
\text { Proportion of the population aged } 60 \text { and } \\
\text { above (\%) }\end{array}$ & $\begin{array}{l}\text { 公园编号 } \\
\text { Park } \\
\text { number }\end{array}$ & $\begin{array}{c}\text { 公园名称 } \\
\text { Park name }\end{array}$ & $\begin{array}{r}\text { 面积 }\left(\mathrm{m}^{2}\right) \\
\text { Area }\left(\mathrm{m}^{2}\right)\end{array}$ \\
\hline \multirow{6}{*}{$\begin{array}{l}\text { 中心城区 } \\
\text { Central } \\
\text { districts }\end{array}$} & $\begin{array}{l}\text { 虹口区 } \\
\text { Hongkou District }\end{array}$ & 37.85 & 1 & $\begin{array}{l}\text { 四川北路公园 } \\
\text { Sichuan North Road Park }\end{array}$ & 42,400 \\
\hline & \multirow[t]{2}{*}{$\begin{array}{l}\text { 黄浦区 } \\
\text { Huangpu District }\end{array}$} & \multirow{2}{*}{37.28} & 2 & $\begin{array}{l}\text { 蓬莱公园 } \\
\text { Penglai Park }\end{array}$ & 27,600 \\
\hline & & & 3 & $\begin{array}{l}\text { 古城公园 } \\
\text { Gucheng Park }\end{array}$ & 38.800 \\
\hline & \multirow[t]{3}{*}{$\begin{array}{l}\text { 普陀区 } \\
\text { Putuo District }\end{array}$} & \multirow{3}{*}{36.97} & 4 & $\begin{array}{l}\text { 曹杨公园 } \\
\text { Caoyang Park }\end{array}$ & 22,593 \\
\hline & & & 5 & $\begin{array}{l}\text { 祥和公园 } \\
\text { Xianghe Park }\end{array}$ & 30,000 \\
\hline & & & 6 & $\begin{array}{l}\text { 真如公园 } \\
\text { Zhenru Park }\end{array}$ & 45,783 \\
\hline \multirow{6}{*}{$\begin{array}{l}\text { 排中心城区 } \\
\text { Outer } \\
\text { districts }\end{array}$} & $\begin{array}{l}\text { 崇明区 } \\
\text { Chongming District }\end{array}$ & 35.28 & 7 & $\begin{array}{l}\text { 瀛洲公园 } \\
\text { Yingzhou Park }\end{array}$ & 43,900 \\
\hline & \multirow[t]{3}{*}{$\begin{array}{l}\text { 宝山区 } \\
\text { Baoshan District }\end{array}$} & \multirow{3}{*}{33.33} & 8 & $\begin{array}{l}\text { 友谊公园 } \\
\text { Youyi Park }\end{array}$ & 44,100 \\
\hline & & & 9 & $\begin{array}{l}\text { 泗塘公园 } \\
\text { Sitang Park }\end{array}$ & 45,021 \\
\hline & & & 10 & $\begin{array}{l}\text { 大华行知公园 } \\
\text { Dahuaxingzhi Park }\end{array}$ & 58,000 \\
\hline & \multirow[t]{2}{*}{$\begin{array}{l}\text { 嘉定区 } \\
\text { Jiading District }\end{array}$} & \multirow{2}{*}{32.72} & 11 & $\begin{array}{l}\text { 马陆公园 } \\
\text { Malu Park }\end{array}$ & 33,350 \\
\hline & & & 12 & $\begin{array}{l}\text { 汇龙潭公园 } \\
\text { Huilongtan Park }\end{array}$ & 46,667 \\
\hline
\end{tabular}

表格中的人口比例数据来源于参考文献[19]

NOTE

The proportion of population is sourced from Ref. [19].

4) 心跳时间指基站和移动 终端（手机）彼此确认 “存活”、交换信息的 时间间隔。

(4) Heartbeat time is the regular interval for both base stations and mobile devices (mobile phones) when sending signals and exchanging messages
为2019年7月。每条数据都包含对应设施名称、经纬度等基本信息。

4 ) 手机信令数据, 来自上海中国移动公司, 获取时间为 2019 年 9 月3 17日。用户的电话和短信接收发、位置变动, 以及每30分钟一次 的基站心跳时间 ${ }^{4}$ 都会产生记录，每条记录都包含用户ID、年龄、性 别、行动轨迹及对应基站经纬度、活动时刻等基本信息。基站密度基 于人口密度设置, 保证了本研究数据的准确性。

\section{2 技术流程}

研究技术路线如图 2 所示, 共分为数据提取与预处理、社区公园游

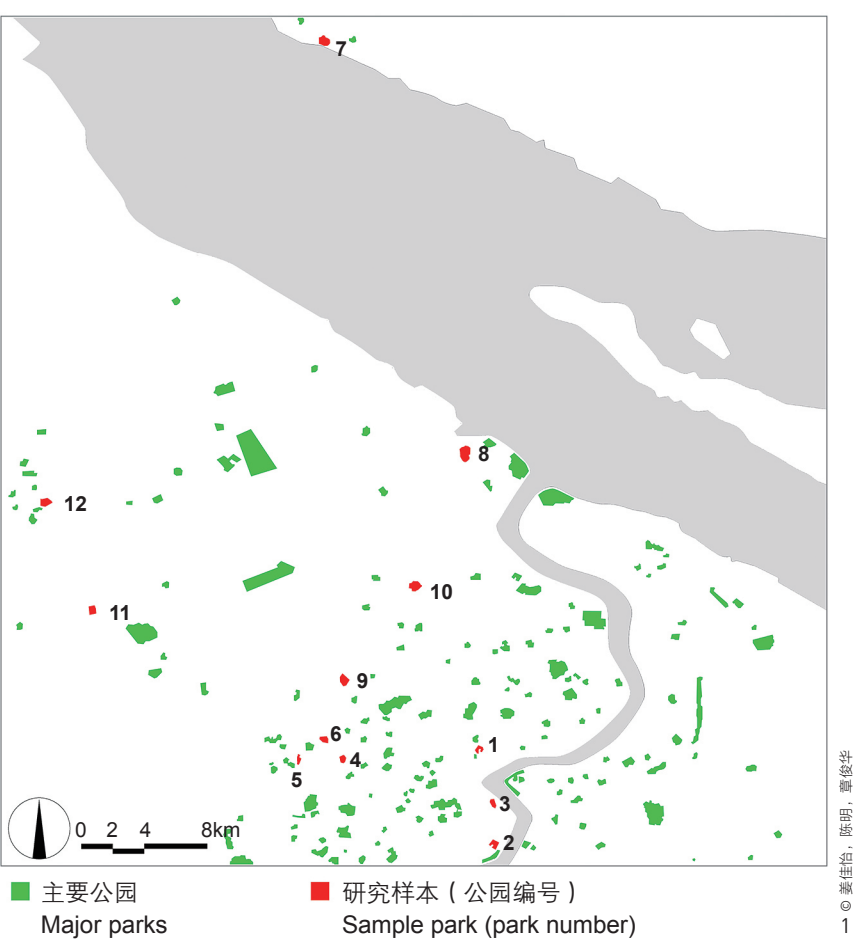

\footnotetext{
上海市主要公园绿地和 研究样本

1. Major parks and sample parks in Shanghai
}

name of facility, and the corresponding latitude and longitude.

4) China Mobile Communications Group Co., Ltd, Shanghai, for the mobile phone signaling data from September 3 to 17, 2019; The calls, messages, and location changes of each mobile phone user were recorded based on the 30-minute heartbeat time ${ }^{\circledR}$ of base station; Each recording contains a user ID, age, gender, mobility, the exact location of the corresponding base station and time; The distribution density of base stations is decided by population density, which ensures the data's accuracy.

\subsection{Research Framework}

Figure 2 depicts the research framework performed in ArcGIS 10.7 and FME 2019.0, which consists of data pre-processing, identifying park users and their corresponding living places, 
客及其居住地识别、量化城市设施空间分布密度及混合度和老年人出 行特征与影响因素的多元线性回归分析 4 个部分。

\subsection{1 数据提取与预处理}

对带有位置信息的POI数据和AOI数据进行坐标纠偏、POI数据重分 类及 $\mathrm{AOI}$ 数据面分类与提取。将POI数据分为交通、工业、居住、公共 设施、商业和绿地共 6 大类, 为避免不同类别数据量差对结果的影响, 对 数据进行标准化处理, 并以直径为 $2 \mathrm{~km}$ 的正六边形网格划分研究单元。

\subsection{2 社区公园游客及其居住地识别}

研究通过F ME 2019.0连接移动用户行动轨迹至对应基站, 并利用 ArcGIS 10.7根据基站位置生成泰森多边形作为基站覆盖区域（图3）。 当超过 $50 \%$ 的基站覆盖区域，或该基站覆盖区域内超过 $50 \%$ 的POI数据 位于研究单元内, 则定义该基站为对应研究单元基站 ${ }^{[37]}$; 同理, 可定义 quantifying the distribution density and the mixture degree of urban facilities, and conducting multiple linear regression on the traveling behaviors of elderly adults and associated contributory factors.

\subsubsection{Data Pre-processing}

In this stage, correction in the coordinates of POI and AOI data, POI reclassification, and AOI classification and extraction were performed. The POI data were classified into 6 categories, namely transportation, industrial, residential, public facility, commercial, and green space. All data were standardized to avoid the magnificent difference of data amount. The study area was divided by a grid of regular hexagonal with a diameter of $2 \mathrm{~km}$, and each of them is a unit in this research.

\subsubsection{Identification of Community Park Users and Their Living Places}

With FME 2019.0, mobility records were connected with base stations. The coverage of each base station, in shape of Tyson polygon, was identified by ArcGIS10.7 (Fig. 3). When a base station's coverage overlaps in a research unit (i.e. more than half of the coverage area or the POI data were mapped within the unit), the base station was considered corresponding to the unit ${ }^{[37]}$. Hence, the base stations of the community parks studied in this

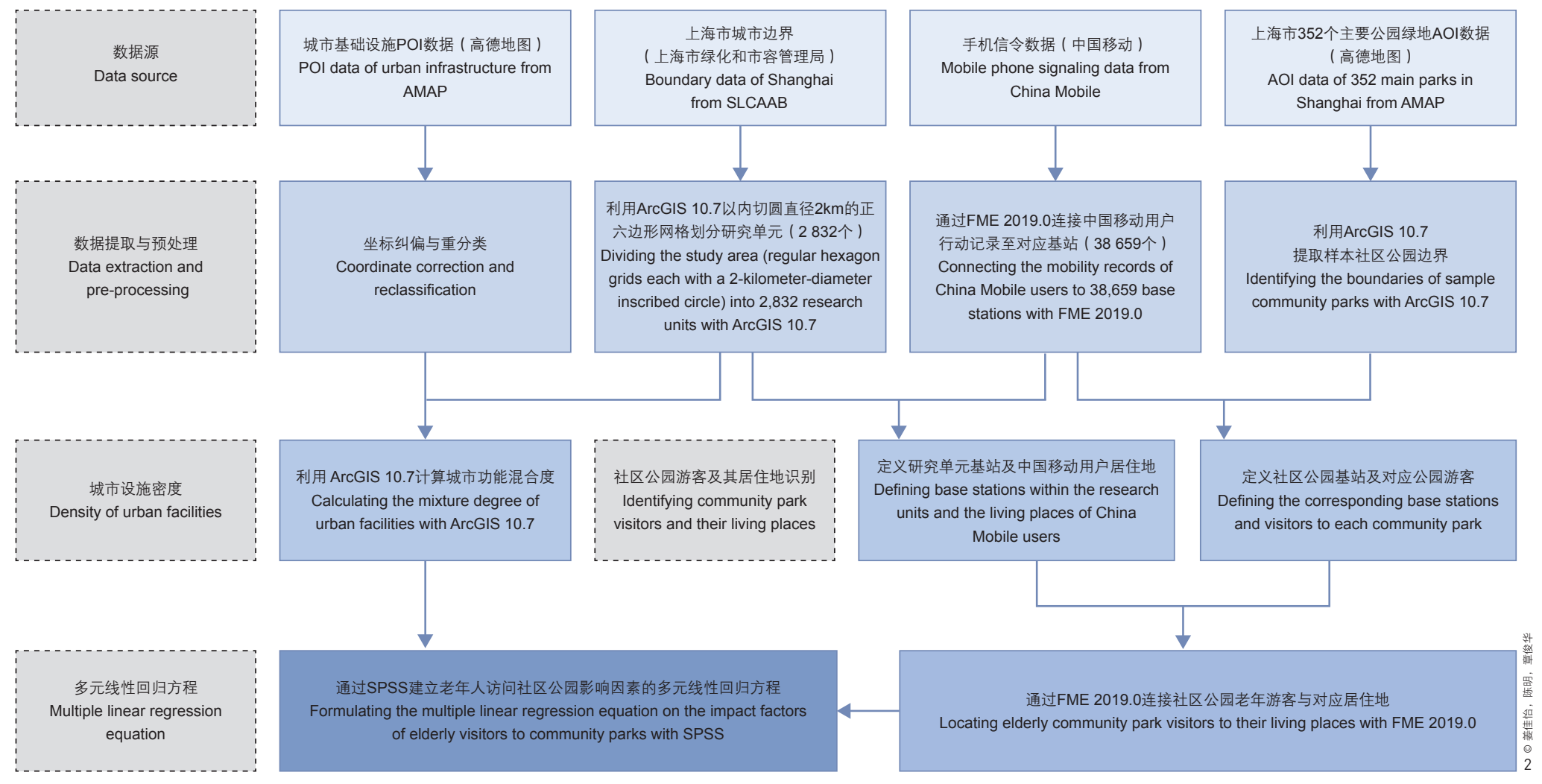



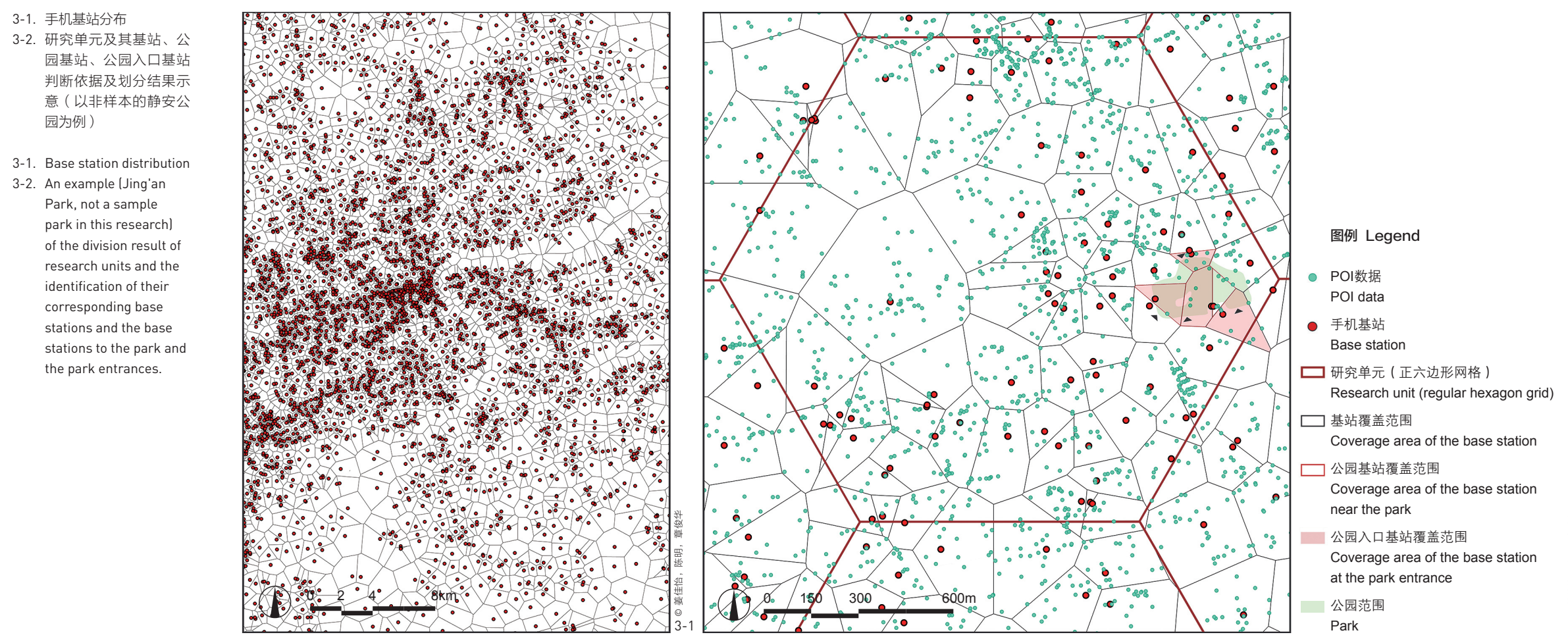

社区公园基站（本研究中每个样本连接的基站数量都大于 3 ）。

为避免路过行人、公园工作人员 ${ }^{[8}$ 对研究结果的影响, 本研究将每 日 6 22 时期间，在目标公园内活动时长为 40 分钟至 6 小时的人员定义为 公园真实游客。由于公园游客至少需要经过公园人口两次, 研究通过 去除在公园人口所在基站处只有一条活动记录的人员，来避免记录基 站覆盖的公园外部其他设施的使用者信息。

研究界定每日24时至次日6时用户活动时间最长的基站所在研究单 元为其居住地, 并通过F ME 2019.0连接公园游客及其居住地所在网格 位置。

\subsection{3 城市功能设施混合度定义}

研究单元各大类城市设施分布密度的计算公式如下:

$$
D_{e}=\frac{n_{e}}{N_{e}}
$$

式中, $e$ 代表某类城市 $\mathrm{POI}$ 数据 $\left(D_{1}\right.$ 为交通、 $D_{2}$ 为工业、 $D_{3}$ 为居 住、 $D_{4}$ 为公共设施、 $D_{5}$ 为商业、 $D_{6}$ 为绿地 $), n_{\mathrm{e}}$ 代表每个研究单元内第 $e$ 类POI的数量, $N_{\mathrm{e}}$ 代表该类设施POI的总数, $D_{\mathrm{e}}$ 则为研究单元内该类设 施的分布密度。研究通过6类城市设施的空间分布的离散程度一一即各 research were identified, and each park corresponds to three base stations at least.

Besides, park visitors were identified as the persons who spend more than 40 minutes but less than 6 hours in the park, from 6:00 to 22:00, to eliminate passers-by and park staff ${ }^{[8]}$. The research also eliminated the single-visits recorded by the base stations corresponding to the park entrance area, and because actual park visitors are supposed to go through the park accesses twice at least.

The research defined park users' living places by locating the unit where the user mostly stays in during 0:00 am to 6:00 am, with FME 2019.0.

\subsubsection{The Mixture Degree of Urban Facilities}

The distribution density of urban facilities in each research unit was calculated according to the following formula:

$$
D_{e}=\frac{n_{e}}{N_{e}}
$$

where e stands for the given POI category $\left(D_{1}\right.$ for transportation, $D_{2}$ for industrial, $D_{3}$ for residential, $D_{4}$ for public facilities, $D_{5}$ for commercial, and $D_{6}$ for green space); $n_{\mathrm{e}}$ is the POI quantity of the category within a given research unit; $N_{e}$ is the total POI number of the category; $D_{\mathrm{e}}$ is the distribution 
研究单元内 $D_{e}$ 的平均绝对偏差 (MAD值) ${ }^{[38]}$ —来反映城市功能混合 度。MAD值与城市功能混合度负相关, MAD值越大, 表示城市功能越 单一。

\subsection{4 老年游客出行特征与影响因素多元线性回归分析}

研究通过构建多元线性回归方程, 来量化社区公园周边及老年游 客居住地周围城市功能混合度, 老年游客居住地与社区公园之间的出 行距离、老年游客居住地人口密度及其老龄人口密度等因素, 对老年 游客访问社区公园的影响, 公式如下:

$$
C N_{i j}=\alpha_{0}+\alpha_{1} D I S_{i j}+\alpha_{2} M A D_{i}+\alpha_{3} I J_{i j} M A D_{j}+\alpha_{4} P H_{i}+\alpha_{5} P O_{i}
$$

式中, $C N_{i j}$ 表示从居住地 $i$ 前往社区公园 $j$ 的老年游客量（人次）, $\alpha_{0}$ 为常数, $\alpha_{1} 、 \alpha_{2} 、 \alpha_{3} 、 \alpha_{4} 、 \alpha_{5}$ 为对应自变量系数, $D I S_{i j}$ 为居住地 $i$ 至社区公园 $j$ 的路网距离 (即通过ArcGIS 10.7测算路网距离, 老年游客 从居住地到达社区公园的最短距离) $; M A D_{i}$ 和 $M A D_{j}$ 分别为老年游客居 住地和访问的社区公园所在研究单元城市功能混合度, 并通过参数 $I J_{i j}$ 确定游客居住地所在研究单元与社区公园所在研究单元是否一致— 若研究单元编号 $i=j$, 则 $I J_{i j}=0$, 反之, 则 $I I_{i j}=1$ 。 $P H_{i}$ 为老年游客的居住 地研究单元内的人口密度, $P O_{i}$ 为该居住地研究单元内的老龄人口密度 （通过FME 2019.0测算研究单元内居民数量）。通过对数变换提高模型 稳定性后, 最终得到老年游客访问社区公园与其影响因素的多元线性 回归方程:

$$
\begin{gathered}
L C N_{i j}=\beta_{0}+\beta_{1} \log \left(D I S_{i j}\right)+\beta_{2} \log \left(M A D_{i}\right)+\beta_{3} I J_{i j} \log \left(M A D_{j}\right) \\
+\beta_{4} \log \left(P H_{i}\right)+\beta_{5} \log \left(P O_{i}\right)
\end{gathered}
$$

为了测算中心城区和非中心城区老年人访问公园的影响因素差 异, 研究分别计算了社区公园所在研究单元位于中心城区和非中心城 区的方程结果。

\section{4 研究结果}

\section{1 社区公园使用情况}

研究在排除由于定位误差引起的异常值后, 得到 12 个社区公园日 均游客总量及老年游客占比（表 2 )。由表 1 和表 2 可见, 中心城区老 density of the POI of the category. The overall mixture degree of urban facilities of each unit thus can be quantified by the spatial dispersion of the 6 POI categories, i.e. the mean absolute deviation $(\mathrm{MAD})^{[38]}$ value of $D_{e} \mathrm{~s}$ of each unit. The MAD value is negatively correlated with the mixture degree of urban facilities; the larger the MAD value is, the less diversity of urban facilities the unit has.

3.2.4 Multiple Linear Regression on the Traveling Behaviors of Elderly Users and the Impact Factors

A multiple linear regression equation was used to quantify the mixture degree of urban facilities around the study community parks and the living places of elderly users, the traveling distance between their living places to the community park, the population density and the aging population density of the area where they live:

$$
C N_{i j}=\alpha_{0}+\alpha_{1} D I S_{i j}+\alpha_{2} M A D_{i}+\alpha_{3} I J_{i j} M A D_{j}+\alpha_{4} P H_{i}+\alpha_{5} P O_{i}
$$

where $C N_{i j}$ is the number of elderly visitors (by person-times) from their living places $i$ to a given community park $j ; \alpha_{0}$ is a constant, and $\alpha_{1}, \alpha_{2}, \alpha_{3}, \alpha_{4}$, and $\alpha_{5}$ are the independent variable coefficients; $D I S_{i j}$ is the traveling distance between the living places of elderly users to the community park (the shortest distance upon the existing road network calculated with ArcGIS 10.7); $M A D_{i}$ and $M A D_{j}$ are the mixture degree of urban facilities around the study community parks and the area where the elderly users live; $I I_{i j}$ indicates whether the living places and the community park are in the same unit $(=0$ if $i=j$, and $=1, i \neq j) . P H_{i}$ and $P O_{i}$ indicate the population density and the aging population density of the unit where the elderly users live in, respectively, and both were calculated by the corresponding number of mobile users in the research unit, with FME 2019.0. Through log-transformation, for a higher robustness, a final equation was obtained:

$$
\begin{gathered}
L C N_{i j}=\beta_{0}+\beta_{1} \log \left(D I S_{i j}\right)+\beta_{2} \log \left(M A D_{i}\right)+\beta_{3} I I_{i j} \log \left(M A D_{j}\right) \\
+\beta_{4} \log \left(P H_{i}\right)+\beta_{5} \log \left(P O_{i}\right)
\end{gathered}
$$

To measure the disparity between central and outer urban areas, we calculated the final equation for both kinds of research units, separately.

\section{Research Findings}

\subsection{Community Park Usage}

After excluding outliers caused by positioning errors, we obtained the average daily total number of visitors in the 12 


\begin{tabular}{|c|c|c|c|c|c|}
\hline \multicolumn{2}{|c|}{$\begin{array}{l}\text { 所在区域 } \\
\text { Region }\end{array}$} & $\begin{array}{l}\text { 公园名称 } \\
\text { Park name }\end{array}$ & $\begin{array}{c}\text { 游客总量 ( 人次 ) } \\
\text { Number of visitors (person-time) }\end{array}$ & $\begin{array}{l}\text { 老年游客占比 }(\%) \\
\text { Elderly visitor proportion (\%) }\end{array}$ & $\begin{array}{c}\left.\text { 单位面积老年游客量 ( 人次 } / \mathrm{hm}^{2}\right) \\
\text { Number of elderly visitors per unit area } \\
\text { (person-time } / \mathrm{hm}^{2} \text { ) }\end{array}$ \\
\hline \multirow{6}{*}{$\begin{array}{c}\text { 中心城区 } \\
\text { Central districts }\end{array}$} & $\begin{array}{l}\text { 虹口区 } \\
\text { Hongkou District }\end{array}$ & $\begin{array}{l}\text { 四川北路公园 } \\
\text { Sichuan North Road Park }\end{array}$ & 6,949 & 31.79 & 521 \\
\hline & \multirow[t]{2}{*}{$\begin{array}{l}\text { 黄浦区 } \\
\text { Huangpu District }\end{array}$} & $\begin{array}{l}\text { 蓬莱公园 } \\
\text { Penglai Park }\end{array}$ & 5,633 & 36.25 & 740 \\
\hline & & $\begin{array}{l}\text { 古城公园 } \\
\text { Gucheng Park }\end{array}$ & 852 & 29.35 & 64 \\
\hline & \multirow[t]{3}{*}{$\begin{array}{l}\text { 普陀区 } \\
\text { Putuo District }\end{array}$} & $\begin{array}{l}\text { 曹杨公园 } \\
\text { Caoyang Park }\end{array}$ & 9,238 & 36.67 & 1,499 \\
\hline & & $\begin{array}{l}\text { 祥和公园 } \\
\text { Xianghe Park }\end{array}$ & 10,495 & 22.23 & 778 \\
\hline & & $\begin{array}{l}\text { 真如公园 } \\
\text { Zhenru Park }\end{array}$ & 1,773 & 45.05 & 174 \\
\hline \multirow{6}{*}{$\begin{array}{c}\text { 非中心城区 } \\
\text { Outer districts }\end{array}$} & $\begin{array}{l}\text { 崇明区 } \\
\text { Chongming District }\end{array}$ & $\begin{array}{l}\text { 瀛洲公园 } \\
\text { Yingzhou Park }\end{array}$ & 1,292 & 33.8 & 99 \\
\hline & \multirow[t]{3}{*}{$\begin{array}{l}\text { 宝山区 } \\
\text { Baoshan District }\end{array}$} & $\begin{array}{l}\text { 友谊公园 } \\
\text { Youyi Park }\end{array}$ & 2,178 & 39.43 & 195 \\
\hline & & $\begin{array}{l}\text { 泗塘公园 } \\
\text { Sitang Park }\end{array}$ & 11,532 & 29.53 & 756 \\
\hline & & $\begin{array}{l}\text { 大华行知公园 } \\
\text { Dahuaxingzhi Park }\end{array}$ & 10,937 & 46.51 & 877 \\
\hline & \multirow[t]{2}{*}{$\begin{array}{l}\text { 嘉定区 } \\
\text { Jiading District }\end{array}$} & $\begin{array}{l}\text { 马陆公园 } \\
\text { Malu Park }\end{array}$ & 3,803 & 33.23 & 379 \\
\hline & & $\begin{array}{l}\text { 汇龙潭公园 } \\
\text { Huilongtan Park }\end{array}$ & 5,937 & 31.99 & 407 \\
\hline
\end{tabular}

龄人口数量和社区公园的游客总数均高于非中心城区，且中心城区社 区公园老年游客的平均单位面积人次 $\left(629\right.$ 人次 $\left./ \mathrm{hm}^{2}\right)$ 约为非中心城 区 $\left(452\right.$ 人次 $\left./ \mathrm{hm}^{2}\right)$ 的 1.39 倍。虽然中心城区老龄化程度高于非中心 城区，但非中心城区社区公园老年游客的平均占比更高（非中心城区 为 $35.75 \%$, 中心城区为 $33.56 \%$ ）。值得注意的是，位于同一市辖区的 不同公园间老年游客占比存在较大差距。例如，位于普陀区的曹杨公 园、祥和公园和真如公园游客中老年人占比分别为 $36.67 \% 、 22.23 \%$ 和 $45.05 \%$ 。

尽管公园老年游客占比与各区域老龄化程度并不对应，但老龄化 程度是否对老年人访问社区公园存在影响仍需进一步验证。研究通过 community parks and the corresponding proportion of elderly visitors (Table 2). The research found that both the numbers of elderly population and all visitors to community parks in the central districts are higher than those of the outer districts, and the average number of elderly visitors per unit area is 629 persontimes $/ \mathrm{hm}^{2}$ to community parks in central districts, 1.39 times that of outer districts (452 person-times $/ \mathrm{hm}^{2}$ ). Contrarily, the average proportion of elderly visitors to community parks in central districts $(33.56 \%)$ is lower than that of outer districts $(35.75 \%)$, though the former districts see a higher level of aging. Moreover, gaps exist in the elderly visitor proportion in different parks, even among the ones in the same district. For example, the proportion vary a lot among the Caoyang Park, Xianghe Park, and Zhenru Park in Putuo District, i.e. $36.67 \%$, 22.23\%, and $45.05 \%$, respectively.

Although the elderly visitor proportion is not always correlated with the aging degree of each district, its impact on 

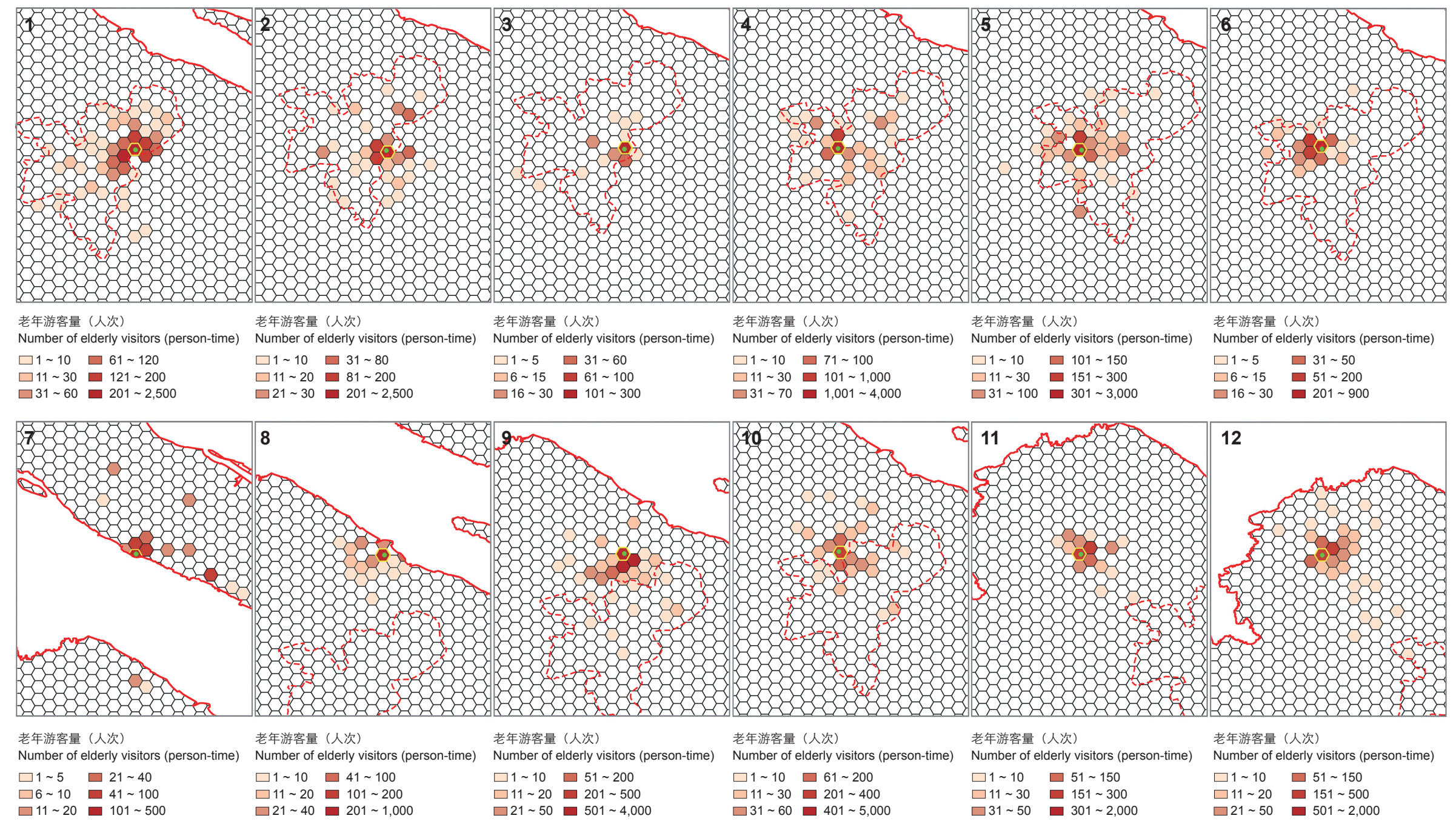

图例 $\square$ 研究单元 Research unit $\square$ 研究范围 Research area - 公园所在研究单元 Research unit covering the park

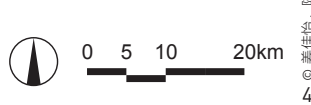

划分正六边形研究单元, 得到了各研究样本老年游客量及其居住地空 间分布的可视化结果（图4)。

\section{2 社区公园老年游客使用差异及影响因素}

表 3 为最终模型的回归结果，模型在 0.001 水平上显著，模型成立。 基于方差膨胀因子 (VIF) 值对自变量是否存在多重共线性进行验证, 排除自变量 $D I S_{i j}, M A D_{i}$ 和 $M A D_{i}$ 的多重共线性。同时, 结果表明 $P H_{i}$ 和 $P O_{i}$ 存在明显的共线性, 这与实际情况吻合, 也即研究单元人口密度与 老龄人口密度存在相关性。根据大卫 - 克莱因鲍姆及布鲁诺 - 贾科米 尼-莎丽等人的研究, 当样本数量较大时, 可以减弱多重共线性对结 果的影响 ${ }^{3991400}$, 因此模型未将以上两个自变量排除。

如表3所示, 模型对 12 个社区公园老年游客访问情况的整体解释 the elderly's visiting behaviors need a further verification. With the regular hexagon grids, the research visualized the number of elderly visitors and their living place distribution (Fig. 4).

\subsection{Usage Differences and Impact Factors of Elderly Visitors to Community Parks}

The regression results shown in Table 3 prove the validation of the final model $(\mathrm{p}<0.01)$. In the research, the effect of multicollinearity of the predictor variables, i.e. $D I S_{i j}, M A D_{i}$, and $M A D_{j}$, was eliminated after the verification measuring the Variance Inflation Factor (VIF). The results also show that variables $P H_{i}$ and $P O_{i}$ are obviously collinear, matching the fact that the total population density of each research unit is
各研究样本老年游客量 及居住地分布
4. The number of elderly visitors and their living place distribution for each sample park


度 $\left(\mathrm{R}^{2}\right)$ 为 0.47 , 说明社区公园和居住地所在区域周边城市功能混合 度、通行距离, 以及居住地所在单元人口总数及老龄人口数是老年人 访问社区公园的重要影响因素。此外，模型对中心城区社区公园老 年游客访问及其影响因素的解释度 $\left(\mathrm{R}^{2}=0.72\right)$ 明显高于非中心城区 $\left(R^{2}=0.40\right)$ 。

为比较各个因素对老年游客量的影响趋势及程度大小, 采用标准 化系数进一步分析。结果表明, 中心城区和非中心城区的 $P H_{i}$ 对公园 老年游客量的正面影响均最强, 同时两类城区中的 $P O_{i}$ 对公园老年游 客量的负面影响也均最强。换言之, 老年人所在居住地的平均人口密 度越高, 越会促使老年人访问当地社区公园; 但是当老龄人口密度过 高时, 会起到相反作用, 使社区公园老年游客量降低。并且, 该负面 影响在中心城区表现更为明显, 其程度是人口密度正面影响程度的 2 倍。当样本扩大至全市所有社区公园时, 我们发现, 人口密度对社区 公园老年人游客量的正面影响与老龄人口密度的负面影响基本持平。 此外, 居住地与公园的出行距离 $\left(D I S_{i j}\right)$ 对老年游客量具有显著负面影 响, 与图4空间分布结果一致, 这一影响在中心城区明显高于非中心城 区。整体而言, 城市功能混合度与中心城区社区公园的老年游客量正相 关, 而与非中心城区老年游客量负相关, 但关联性弱, 且并不显著。模 型未能解释不同城市功能混合度差异与老年人访问社区公园的关系。

\section{5 讨论}

社区公园作为社区生活圈的重要组成部分, 对推动老年人友好 型公共服务设施更新具有重要意义。然而鲜少有研究从城市结构差异 的角度出发, 量化不同区域老年人访问社区公园的行为差异及影响因

表3: 最终模型多元线性回归方程结果

Table 3: Results of multiple linear regression equations of the final equation

\begin{tabular}{|c|c|c|c|c|c|c|c|c|c|c|}
\hline $\begin{array}{l}\text { 地区范围 } \\
\text { Region }\end{array}$ & $\beta_{0}$ & $\boldsymbol{\beta}_{1}$ & $\beta_{2}$ & $\beta_{3}$ & $\boldsymbol{\beta}_{4}$ & $\beta_{5}$ & $\mathbf{R}^{2}$ & $\begin{array}{c}\text { 调整后 } \mathrm{R}^{2} \\
\text { Adjusted } \mathrm{R}^{2}\end{array}$ & $\mathrm{~F}$ & Sig. \\
\hline $\begin{array}{c}\text { 全市 } \\
\text { Whole city }\end{array}$ & -0.52 & $-0.66 * *$ & 0.03 & 0.01 & $1.26^{*}$ & $-1.24^{* *}$ & \multirow[t]{2}{*}{0.47} & \multirow[t]{2}{*}{0.44} & \multirow[t]{2}{*}{12.68} & \multirow[t]{2}{*}{$0.000^{* *-}$} \\
\hline VIF & - & 1.07 & 1.07 & 1.09 & 113.32 & 112.32 & & & & \\
\hline $\begin{array}{c}\text { 中心城区 } \\
\text { Central districts }\end{array}$ & -8.02 & $-0.86^{* *}$ & -0.05 & -0.18 & $0.46^{*}$ & $-0.97^{* *}$ & \multirow[t]{2}{*}{0.72} & \multirow[t]{2}{*}{0.67} & \multirow[t]{2}{*}{17.09} & \multirow[t]{2}{*}{$0.000^{* * *}$} \\
\hline VIF & - & 1.07 & 1.24 & 1.19 & 119.73 & 116.12 & & & & \\
\hline $\begin{array}{c}\text { 非中心城区 } \\
\text { Outer districts }\end{array}$ & 0.29 & $-0.54^{* *}$ & $0.09 * *$ & 0.10 & $0.65^{*}$ & -0.57 & \multirow[t]{2}{*}{0.40} & \multirow[t]{2}{*}{0.30} & \multirow[t]{2}{*}{4.06} & \multirow[t]{2}{*}{$0.006^{* *}$} \\
\hline VIF & - & 1.11 & 1.19 & 1.16 & 126.99 & 120.54 & & & & \\
\hline
\end{tabular}

注

*代表 $p<0.1 ， * *$ 代表 $p<0.05 ， * * *$ 代表 $p<0.001$ 。

NOTE

"means $p<0.1,{ }^{* *}$ means $p<0.05$, and ${ }^{* * *}$ means $p<0.001$ correlated with the elderly population density. This research did not exclude the two variables as David G. Kleinbaum and Bruno Giacomini Sari et al. have confirmed that the effect of multicollinearity on the results can be ignored ${ }^{[39[40]}$ when the sample size is large.

Also in Table 3, the explanatory power $\left(\mathrm{R}^{2}\right)$ of the model quantifying the community park usage by elderly visitors in the 12 samples is 0.47 , indicating that the core impact factors include the mixture degree of urban facilities near the community parks and the elderly's living places, the traveling distance, and the total and elderly populations of the research unit where the elderly live. In addition, this explanatory power for central districts $(0.72)$ is significantly higher than that of outer districts (0.40).

In the next step, standardized coefficients were used to evaluate the impact level of each factor. The results show that $\mathrm{PH}_{i}$ of both the central and outer districts has the most positive impact on the elderly's visiting behaviors to community parks, while $P O_{i}$ of both kinds of urban areas has the most negative impact. In other words, the higher the average population density in the living spaces of the elderly is, the more community park visits by the elderly there will be. On the contrary, an excessively high elderly population density may lead to lower visits by the elderly, especially to the central districts where the negative impact is significantly as twice as the positive impact of population density. However, when regarding all the community parks in Shanghai, the gap between the positive impact and negative impact narrows to a rough even degree. The research also indicates a similar result to Figure 4 that the factor of $D I S_{i j}$ had a greater negative impact on the number of elderly visitors, especially in central districts. Overall, the mixture degree of urban facilities has a positive correlation with the number of elderly visitors to community parks in central districts, while having a weak and non-significant negative correlation in outer districts. But our model is unable to explain how varied mixture degrees impact the elderly visitors' usage of community parks.

\section{Discussions}

Community parks, as a critical component of communitylife circles, are vital to the promotion of the elderly-friendly public facilities in cities. However, quantitative research on the behavioral differences and related impact factors of the elderly's visiting behaviors to community parks is less studied from the perspective of urban structural differentiations. In hope of to narrow this gap, the research investigated the elderly 
素。本研究期望就上海市中心城区和非中心城区老年人访问社区公园 的差异及主要影响因素展开讨论, 为老年人友好型社区公园的规划设 计提供针对性建议。

\section{1 主要发现}

首先，居住区老龄人口密度对老年人访问城市公园具有显著的负 面影响，即老龄化程度的加深反而不利于老年人使用社区公园。这可 能与中国城市公园使用者中老年人比例较高有关 ${ }^{[4]}$ 。另有部分研究认 为, 具有相对稳定社交生活圈的老年人生活更加规律且幸福感更高 ${ }^{[22]}$ 。 当周边老年人占比较高时, 稳定的社交圈使得老年人活动类型选择更 加丰富, 访问公园的频率就会相应降低。但也有研究认为, 社会包容 性不足使得老年人缺乏进入城市公园的意愿，从而限制了老年人的活 动范围 ${ }^{[3][4]}$ 。老龄化程度较高的社区中 80 岁以上高龄老年人的占比也相 对较高 ${ }^{[19]}$, 受自身身体机能限制, 高龄老年人的出行范围较小, 访问绿 地或其他城市设施的频率也较低。此外, 人口密度对老年人访问社区 公园的影响还与公园区位及城市分化有关: 中心城区社区公园潜在的 老年使用者数量受到人口密度的正面影响更大, 受老龄人口密度的负 面影响更大。

第二, 除以往研究所考虑的房价 ${ }^{[8]}$ 、可达性 ${ }^{[43]}$ 、安全性 ${ }^{[4]}$ 等因素 $^{\text {究 }}$ 外, 本研究发现, 人口密度对老年人访问城市公园的情况有显著且较 强影响。阿代尔 - 特纳指出, 相比人口老龄化程度, 人口密度对英国 社会福利的负面影响更显著 ${ }^{[3]}$ 。但本研究结果显示, 人口密度与老年人 访问城市社区公园呈正相关, 这一影响在非中心城区明显显著于中心 城区。与此相反, 老龄人口密度是影响老年人访问社区公园的显著负 面因素，并且在中心城区表现出显著影响。

第三，非中心城区社区公园的老年游客分布范围相对更广，这 表明出行距离对非中心城区老年人访问社区公园的负面影响小于中 心城区。尽管有研究认为, 相比城市外围, 中心城区老年人的可达性 更高 ${ }^{[15]}$, 但在评估可达性时还应考虑人们对周边环境的感知 ${ }^{[3][42]}$ 。本研 究的结果表明, 城市功能混合度对中心城区和非中心城区老年人社区 公园访问情况影响机制截然相反。非中心城区城市功能混合度不足, from central and outer districts in Shanghai, so as to provide specific suggestions for the planning and design of elderlyfriendly community parks.

\subsection{Main Findings}

First of all, a larger population density of the elderly in a certain living space, i.e. a higher degree of aging, may impede the elderly' visits to community parks. This is might be a result of the relative high ratio of elderly users of urban parks in China ${ }^{[41]}$. Other research suggests that a relatively stable social circle for the elderly may bring them a more regular daily life and a higher sense of happiness ${ }^{[42]}$ : they would meet with more friends and have a higher variety of outdoor activities, meaning a lower demand of visiting parks. However, other researchers found that a less inclusive society may also depress the elderly to visit parks, lowering their variety of outdoor activities ${ }^{[3][41]}$. Moreover, a higher aging degree of a community means that there will be more people aged above $80^{[19]}$, whose travel range is more subject to their physical functions, and a lower use of green spaces and other facilities. Finally, the factors of park location and urban differentiation also magnify the impact of population density on the elderly's visit to community parks: the number of potential elderly users of community parks in central districts is positively correlated with the population density, and negatively correlated with the elderly population density.

Secondly, in addition to factors such as housing price ${ }^{[8]}$, accessibility ${ }^{[43]}$, and safety ${ }^{[44]}$ that were examined in existing studies, this research found that the population density has a significant and strong impact on the elderly's visits to urban parks. Different from Adair Turner's suggestion that the population density, compared with the aging degree, would have a worse effect on the British social welfare ${ }^{[34]}$, the results of this study show that the population density is positively correlated with the elderly's visits to urban community parks, especially in outer districts. Conversely, a larger aging population means a lower use of urban parks by the elderly, which is more obvious in central districts.

Thirdly, elderly visitors to community parks in outer districts lived relatively farther than the visitors in central districts which shows that the negative impact of traveling distance factor is less significant in outer districts. Although some research evidences that the accessibility is more favorable for the elderly in central districts $^{[15]}$, people's perception of the surroundings should also be considered when evaluating accessibility ${ }^{[3][42]}$. Findings of this research may support this statement: in outer districts with a low mixture degree of urban facilities, the elderly have to visit some community parks far away from their living spaces; 
促使该地区老年人访问居住地以外街区的社区公园，而中心城区社区 公园周边完善的城市设施吸引了老年人的访问。因此, 上海市非中 心城区社区公园服务范围更广, 这可能是由于城市设施不足导致的 非自愿出行。

\section{2 老年人友好型社区公园规划设计策略}

考虑到社区公园对老年人身心健康的益处, 以及老年人年龄和 身体局限性, 对上海市老年人友好型社区公园规划设计建议如下: 社 区公园服务范围应充分考虑老年人活动特征, 结合居住区老龄人口密 度, 适当缩小预期服务范围。其中, 中心城区社区公园预期服务范围 更小, 因此建设密度和数量需高于非中心城区。考虑到出行距离与中 心城区老年人访问社区公园呈显著负相关, 在不改变现有城市结构的 基础上, 可以考虑增加小尺度高密度城区的社区公园规划。而在非 中心城区, 较低的城市功能混合度对老年人的非自愿出行具有潜在影 响, 因此社区公园的数量有待提升。相比中心城区, 完善非中心城区 城市功能、缩短出行距离, 更有利于缓解该地区老年人访问社区公园 的环境公平问题。此外, 为了降低城市分化对老年人访问社区公园公 平性的进一步影响, 有必要针对不同区位及不同老龄化程度的街区, 提出更为详细的规划指南。

\section{6 结论与展望}

社区公园是评估老年人出行友好性的关键组成, 城市分化导致了 中心城区和非中心城区老年人访问社区公园影响机制的差异。本研究 基于手机信令数据, 设计了一个多元线性回归模型, 分析了老年人访 问社区公园的活动差异及影响因素。研究发现, 居住地的人口密度及 其老龄人口密度、出行距离是影响老年人访问社区公园的重要因素。 并且, 中心城区和非中心城区社区公园老年游客使用社区公园的影响 机制存在差异, 有必要制定针对不同区域社区公园的规划设计准则。 本研究主要结论如下:

1 ) 老年人所在居住区人口密度及其老龄人口密度是评估老年人访 问社区公园的不可忽略的重要影响因素, 应作为参考指标纳人社区公 whereas, fully-equipped facilities near community parks in the central districts would attract more elderly visitors. Therefore, the wider service range of community parks in the outer districts in Shanghai might result from the elderly's passive visits to the parks due to a lack of urban facilities.

\subsection{Strategies for the Planning and Design of Elderly-Friendly Community Parks}

Community parks are beneficial to the elderly's mental and physical health. Taking also their age and physical limitations into account, some suggestions are made here for the planning and design of the elderly-friendly community parks in Shanghai. The service radius of community parks can be sized down to match the elderly's behavior patterns and the elderly population density; for the central districts, an even smaller service radius necessitates a denser and larger number of community parks. Given that the urban structure is hardly to change, planners could introduce more smaller-scale community parks into the central districts to mitigate the impact of traveling distance on the elderly's visit to parks. For outer districts, an increased quantity of community parks may encourage more active visits. In this regard, better-equipped and -mixed supporting urban facilities and shorter traveling distance would all contribute to realizing the environmental justice for the elderly to visit community parks. More targeted plans or guidelines should be proposed to solve specific problems caused by site locations and varied aging degrees to reduce the impact of urban differentiation.

\section{Conclusions and Prospects}

Community park is one type of key urban facilities for assessing travel-friendliness to the elderly. Meanwhile, urban differentiation has led to varied impacts on the elderly's visit to community parks in central and outer districts. Utilizing mobile phone signaling data, this study analyzed the elderly's visiting behaviors to community parks in Shanghai and related impact factors via a multiple linear regression model. The research results imply that the total and elderly population densities within a certain living place, and the traveling distance are significant impact factors. Moreover, the elderly from central districts behave differently from their counterparts in outer districts, which necessitates specific planning and design guidelines for different demographic regions. The main conclusions of this study include three aspects:

1) The important factors of both the total and elderly population densities in a specific living space should be 
园规划设计中。但人口密度对非中心城区老年人访问社区公园的正面 影响明显小于中心城区。

2 ) 出行距离对老年人访问社区公园具有显著负面影响, 且该影响 对中心城区老年人更为明显。说明基于老年人出行特征的社区公园实 际服务范围很可能小于规划预期的服务范围, 中心城区社区公园潜在 服务的老年人范围相比非中心城区更小。

3 ) 居住地城市设施建设情况对中心城区和非中心城区老年人访问 社区公园的影响机制截然不同, 居住地和社区公园周边城市功能混合 度较高可促进中心城区老年人对社区公园的访问。而在非中心城区, 居住地周边欠完善的城市设施则促使老年人访问社区公园。

本研究也存在一定的局限性。首先, 虽然本研究针对基于手机 信令数据的小尺度公园游客的定位设计了数据清洗步骤, 但仍然无法 避免因基站密度不足、定位错误、手机信令数据精度不足等因素造成 的数据误差。此外, 研究虽然对老年人访问社区公园的整体情况及中 心城区和非中心城区的差异进行了量化分析, 但尚不足以剖析这些差 异产生的原因。很多潜在因素一一如收人水平、汽车保有量、是否持 有驾照、个体主观能动性、家庭背景等——都可能影响老年人访问社 区公园的意愿。技术难点在于, 以上潜在因素的统计结果大多以街区 或市辖区为范围公开, 难以与个体访问行为直接关联。在自变量选择 及量化方面, 研究通过MAD值量化城市功能混合度, 只能反映不同 功能的离散程度, 而无法反映数量是否能够满足居民需求。此外, 自 变量过于交叉会影响模型的稳定性及准确性, 进而影响结果准确性。 未来, 研究将尝试通过贝叶斯线性回归模型等对现有数据进行优化建 模, 并综合更多以上变量, 了解社会空间环境及个体差异对老年人访 问社区公园的影响机制, 以期为老龄化社会社区生活圈公园绿地规划 设计提供更具指导意义的参考。LAF given particular considerations in the planning and design of community parks. Moreover, to outer districts, the factor of total population density is less significantly correlated with the elderly's visits to community parks.

2) Traveling distance has a significant negative impact on the elderly's visits to community parks, especially in central districts. This finding reveals that the actual service radius of community parks may fail to meet the planned coverage because the elderly's behavior is heavily subject to their physical functions. Meanwhile, the potential service radius of the community parks in central districts is smaller than that in outer districts.

3) The settings of urban facilities in a certain living place impact differently on the elderly's visits to community parks in highly differentiated regions. The higher mixture degree of urban facilities near a living place and a community park in central districts may encourage their visits. But in outer districts, the poorness of supporting urban facilities would promote seniors' usage of community parks.

There are, inevitably, certain limitations in this study. First of all, although the study designed data cleaning steps for the locations of visitors to small-scale parks using mobile phone signaling data, errors caused by the insufficiency of base station density, improper positioning, and inaccurate signaling data are unavoidable. Secondly, the research briefly quantified the overall visiting pattern of the elderly to community parks and the differences between the central and outer districts, and is insufficient to clarify such differences. Other factors, such as income level, car ownership, with or without driving license, individual preference and willingness, and family background may all affect their choice in park visiting. However, such personal data are often hardly available from neighborhoodor district-scale statistics. Thirdly, in selecting and quantifying independent variables, the study used the MAD value to indicate the mixture degree of urban facilities. But this value can only indicate the dispersion degree of different facilities, instead of citizens' satisfaction level on the number of facilities. In addition, strongly correlated independent variables will affect the stability and accuracy of the model, and even the final results. To solve this problem, the authors will try to optimize the research modeling of existing data by adopting other models such as the Bayesian Linear Regression model, and integrate more of variables mentioned above to better understand the impacting mechanism of social-spatial environment and individual differences on the elderly's visits to community parks. All such efforts may provide more suited guidance to the planning and design of parks for the building of community-life circles of the aging society. LAF 
[1] National Bureau of Statistics of China. (2020). Statistical Communique of the People's Republic of China on the 2019 National Economic and Social Development. Beijing, China: China Statistics Press.

[2] Maas, J., Verheij, R. A., de Vries, S., Spreeuwenberg, P., Schellevis, F. G., \& Groenewegen, P. P. (2009). Morbidity is related to a green living environment. Journal of Epidemiology and Community Health, 63(12), 967-973. doi:10.1136/ jech.2008.079038

[3] Xie, B., An, Z., Zheng, Y., \& Li, Z. (2018). Healthy aging with parks: Association between park accessibility and the health status of older adults in urban China. Sustainable Cities and Society, (433), 476-486. https://doi.org/10.1016/ j.scs.2018.09.010

[4] Luo, T., Tang, J., \& Liu, Y. (2011). Sustainability of Recreationa Travel to Parks in Chinese Metropolitan Areas: Case Study in Shanghai. Chinese Landscape Architecture, (7) 87-91. doi:10.3969/.issn.1000-6664.2011.07.021

[5] World Health Organization. (2007). Global Age-Friendly Cities: A Guide. Retrieved from http://www.who.int/ageing/ publications/Global_age_friendly_cities_Guide_English.pd

[6] Loukaitou-Sideris, A., Levy-Storms, L., \& Brozen, M. (2014). Placemaking for an aging population: Guidelines for seniorfriendly parks. Retrieved from https://www.lewis.ucla.edu/ publication/placemaking-for-an-aging-population-guidelinesfor-senior-friendly-parks/

[7] Kabisch, N. \& Haase, D. (2013). Green justice or just green? Provision of urban green spaces in Berlin, Germany. Landscape and Urban Planning, (122), 129-139. https://dol. org/10.1016/j.landurbplan.2013.11.016

[8] Guo, S., Song, C., Pei, T., Liu, Y., Ma, T., Du, Y., ... Wang, Y. (2019]. Accessibility to urban parks for elderly residents: Perspectives from mobile phone data. Landscape and Urban Planning, (1911 103642. https://doi.org/10.1016/j.landurbplan.2019.103642

[9] Wen, C., Albert, C., \& Von Haaren, C. (2018). The elderly in green spaces: Exploring requirements and preferences concerning nature-based recreation. Sustainable Cities and Society, (38), 582-593. https://doi.org/10.1016/ j.scs.2018.01.023

[10] Barham, H., \& Daim, T. (2020). The use of readiness assessment for big data projects. Sustainable Cities and Society, (60), 102233. https://doi.org/10.1016/j.scs.2020.102233

[11] Sina Corporation. (2018). Weibo User Annual Report of 2018. Retrieved from https://data.weibo.com/report/ reportDetail?id=433

[12] GSM Association. (2020). The Mobile Economy China 2020 Retrieved from https://www.gsma.com/mobileeconomy/wpcontent/uploads/2020/03/GSMA_MobileEconomy2020_China_ ENG.pdf

[13] Jiguang Confidential. (2017). Stratagems among China Mobile, China Telecom and China Unicom: Research Report of Cellphone Business Hall of Operators, December, 2017. Retrieved from https://www.jiguang.cn/reports/185

[14] Xiao, Y., Wang, D., \& Fang, J. (2019). Exploring the disparities in park access through mobile phone data: Evidence from Shanghai, China. Landscape and Urban Planning, (181), 80-91. https://doi.org/10.1016/j.landurbplan.2018.09.013

[15] Liu, Y., Fang, F., \& Jing, Y. (2020). How urban land use influences commuting flows in Wuhan, Central China: A mobile phone signaling data perspective. Sustainable Cities and Society, (53), 101914. https://doi.org/10.1016/j.scs.2019.101914
[16] Ma, F. (2020). Spatial equity analysis of urban green space based on spatial design network analysis (sDNA): A case study of central Jinan, China. Sustainable Cities and Society, (60), 102256. https://doi.org/10.1016/j.scs.2020.102256

[17] Cheng, L., De Vos, J., Shi, K., Yang, M., Chen X., \& Witlox, F. (2019). Do residential location effects on travel behavior differ between the elderly and younger adults? Transportation Research Part D: Transport and Environment, (73), 367-380. https://doi.org/10.1016/j.trd.2019.07.015

[18] Bureau of Statistics of Shanghai. (2018, November 23). Curren situation and projection of aging population in Shangha. Retrieved from http://tij.sh.gov.cn/tjfx/20181123/00141002033.htm

[19] Bureau of Statistics of Shanghai. (2019). Shanghai Statistical Yearbook 2019. Retrieved from http://tij.sh.gov.cn/tjnj/2020042 7/4aa08fba106d45fda6cb39817d961c98.htm

[20] Xu, Y., Liao, Z., Zhang, S., Shen, G., Zheng, D., Chen, L., .. Song, W. (2017). Strategic thinking on Shanghai's urban spatial optimization. Urban Planning Forum, (z1), 20-30. doi:10.16361/ j.upf.201707003

[21] Li, M. (2017). The Planning Strategies of a 15-minute Community Life Circle Based on Behaviors of Residents. Urba Planning Forum, (1), 111-118. doi:10.16361/j.upf.201701014

[22] Ministry of Land, Infrastructure, Transport and Tourism of Japan. (1969). The Second Comprehensive National Development Plan. Retrieved from https://www.mlit.go.jp/ common/001135929.pdf

[23] Shanghai Urban Planning and Land Resources Administration Bureau. (2016). Planning guidance of 15-minute communitylife circle: Planning and construction guidance, action guidelines. Retrieved from http://up.caup.net/file/life-circle. pdf

[24] Shanghai Urban Planning and Land Resources Administration Bureau. (2017). Shanghai Master Plan (2017-2035). Shanghai, China: Shanghai Scientific and Technical Publishers.

[25] Ministry of Housing and Urban-Rural Development of the People's Republic of China. (2017). Standard for classification of urban green space (CJJ/T85-2017). Beijing, China: China Architecture and Building Press

[26] Comber, A., Brunsdon, C., \& Green, E. (2008). Using a GISbased network analysis to determine urban greenspace accessibility for different ethnic and religious groups. Landscape and Urban Planning, 86(1), 103-114. https://doi. org/10.1016/j. landurbplan.2008.01.002

[27] Hansen, W. G. (1959). How Accessibility Shapes Land Use. Journal of the American Institute of Planners, 25(2), 73-76. https://doi.org/10.1080/01944365908978307

[28] Natural England. (2010). 'Nature Nearby': Accessible Natural Greenspace Guidance (pp.41-45). Retrieved from http://www. ukmaburbanforum.co.uk/docunents/other/nature nearby pd

[29] Fan, P., Xu, L., Yue, W., \& Chen, J. (2017). Accessibility of public urban green space in an urban periphery: The case of Shanghai. Landscape and Urban Planning. (165), 177-192. https://doi.org/10.1016/j.landurbplan.2016.11.007

[30] Shanghai Landscaping and City Appearance Administrative Bureau. (2020, August 31). Greening and Forestry. Retrieve from http://hsr.sh.gov.cn/lhg//20200831/703d03a0-f35d-44edb660-1f8b97215abf.html

[31] Shenzhen Park Management Center, \& Tropical Landscape Architecture Center of South China Agricultural University. (2015, October). Shenzhen Community Park Construction
Standard. Retrieved from http://www.szis.com.cn/szjseditor/ uploadfile/201512/20151228160029821.pdf

[32] Department of Parks and Recreation Planning and Development Agency. (2017, May). Park Design Guidelines and Standards. Country of Los Angeles. Retrieved from http://file.lacounty.gov/SDSInter/dpr/1029701_ ParkDesignGuideline2017.pdf

[33] Shelton, T., Poorthuis, A., \& Zook, M. (2015). Social media and the city: Rethinking urban socio-spatial inequality using user-generated georaphic information Landscape and Urban Planning, (142), 198-211. https://doi.org/10.1016/ Jrban Planning, (142), $198-21$

[34] Turner, A. (2009). Population ageing: What should we worr about? Philosophical Transactions of the Royal Society B: Biological Sciences. 364(1532), 3009-3021. doi:10.1098/ rstb.2009.0185

[35] Wang, H., Hu, Y., Tang, L., \& Zhuo, Q. (2020). Distribution of Urban Blue and Green Space in Beijing and Its Influence Factors. Sustainability, 12(6), 2252. doi:10.3390/su12062252

[36] Enssle, F., \& Kabisch, N. (2020). Urban green spaces for the social interaction, health and well-being of older peopleAn integrated view of urban ecosystem services and socioenvironmental justice. Environmental Science and Policy, (109) 36-44. https://doi.org/10.1016/j.envsci.2020.04.008

[37] Guo, S., Yang, G., Pei, T., Ma, T., Song, C., Shu, H., ... Zhou, C. (2019). Analysis of factors affecting urban park service area in Beijing: Perspectives from multi-source geographic data. Landscape and Urban Planning, (181), 103-117. https://doi. org/10.1016/ j.landurbplan.2018.09.016

[38] Jiang, J., Dai, F., \& Zhang, J. (2020). Comparative Study of Urban Functional Structure Based on Pol Data: A Case Study of Beijing and Shanghai. Modern Urban Research, (7), 42-50. doi:10.3969/j.issn.1009-6000.2020.07.006

[39] Kleinbaum, D. G., Kupper, L. L., Nizam, A., \& Muller, K. E. (2007). Applied Regression Analysis and Other Multivariable Methods (Duxbury Applied) (4th Edition). Belmont, CA: Duxbury Press.

[40] Sari, B. G., Dal'Col Lúcio, A., Olivoto, T., Krysczun, D. K. Tischler, A. L., \& Drebes, L. (2018). Interference of sample size on multicollinearity diagnosis in path analysis. Pesquisa Agropecuária Brasileira, 53(6), 769-773. https://dx.doi. org/10.1590/s0100-204×2018000600014

[41] Zhang, Y. (2009). Research on the Utilization of Parks by Old People-Taking Jinan City and Tai'an City as Examples (Doctoral dissertation). Shandong Agricultural University, Tai'an.

[42] Chaudhury, H., Campo, M., Michael, Y., \& Mahmood, A. (2016). Neighbourhood environment and physical activity in older adults. Social Science and Medicine, (149), 104-113. doi:10.1016/j.socscimed.2015.12.011

[43] Cheng, L., Caset, F., De Vos, J., Derudder, B., \& Witlox, F. (2019 Investigating walking accessibility to recreational amenities for elderly people in Nanjing, China. Transportation Research Part D: Transport and Environment, (76), 85-99. https://doi. org/10.1016/j.trd.2019.09.019

[44] Milton, S., Mold, A., Tinker, A., \& Herrick, C. (2019). Growing old in new towns: A call for research on health and ageing in planned urban environments. Health and Place, (58), 102166. https://doi.org/10.1016/j.healthplace.2019.102166 